\title{
PENGEMBANGAN PARIWISATA BUDAYA BERBASIS SITUS SEJARAH LOKAL GUNUNG SUSURU DI KABUPATEN CIAMIS
}

\section{DEVELOPING CULTURAL TOURISM BASED ON LOCAL HISTORICAL SITE OF MOUNT SUSURU IN CIAMIS REGENCY}

\author{
Uung Runalan Soedarmo*, Sri Pajriah, Aan Suryana \\ Program Studi Pendidikan Sejarah, FKIP Universitas Galuh \\ Email: runalansoedarmo066@gmail.com \\ (Diterima 20-08-2021; Disetujui 15-09-2021)
}

\begin{abstract}
ABSTRAK
Kegiatan pengabdian dosen kepada masyarakat yang dilakukan mengambil judul "Pengembangan Pariwisata Budaya Berbasis Situs Sejarah Lokal Situs Gunung Susuru di Kabupaten Ciamis”.Sasaran yang dituju dalam pengabdian ini adalah masyarakat yang memiliki pemahaman kurang terhadap pengembangan pariwisata budaya berbasis situs sejarah lokal yang ada di Desa Kertabumi, Kecamatan Cijeunjing, Kabupaten Ciamis. Hal ini dilakukan supaya masyarakat mampu meningkatkan pendapatan dan kesejahteraan mereka. Metode yang digunakan dalam kegiatan pengabdian ini adalah menggunakan metode instruksional, dengan menggunakan pendekatan participatory planning, yaitu suatu pendekatan dimana seluruh unsur yang terlibat dalam perencanaan dan pengembangan kawasan wisata budaya diikutsertakan baik secara teoritis maupun praktis. Selanjutnya menggunakan pendekatan potensi dan karakteristik ketersediaan produk budaya yang dapat mendukung keberlanjutan pengelolaan kawasan wisata budaya. Adapun hasil kegiatan pengabdian adalah bahwa produk wisata yang dikembangkan di Situs Gunung Susuru adalah berupa kerajinan tangan caping (dudukuy) yang terbuat dari hata, namun dalam proses pemasarannya masih belum optimal dikarenakan faktor SDM, analisis faktor internal dan eksternal pengembangan pariwisata budaya berbasis situs sejarah lokal Gunung Susuru meliputi kekuatan, kelemahan, peluang dan ancaman. Sedangkan strategi pengembangan yang digunakan adalah strategi kekuatan peluang, strategi kekuatan ancaman, strategi kelemhan peluang dan strategi kelemahan ancaman.
\end{abstract}

Kata Kunci: Pariwisata; Budaya; Sejarah Lokal, Gunung Susuru

\section{ABSTRACT}

The community service activitie carried out by lecturers take the title " Developing Cultural Tourism Based on Local Historical Site of Mount Susuru in Ciamis regency", Cijeunjing District, Ciamis Regency. The target of this service is people who have a poor understanding of the development of cultural tourism based on local historical sites in Kertabumi Village, Cijeunjing District, Ciamis Regency.This is done so that the community is able to increase their income and welfare. The method used in this community service is the instructional method using a participatory planning approach. It is an approach in which all elements involved in planning and developing cultural tourism areas both theoretically and practically. Furthermore, this service uses a potential approach and the characteristics of the availability of cultural products that can support the sustainability of the management of cultural tourism areas. The result of the community service shows that the tourism products developed at the Mount Susuru Site are in the form of handicraft caping (situy) made of hata. However, in the marketing process is still not optimal due to human resources factor and the analysis of internal and external factors for the development of cultural tourism based on local historical site of Mount Susuru which includes strengths, weaknesses, opportunities and threats. While the development strategy used is the opportunity strength strategy, threat strength strategy, opportunity weakness strategy and threat weakness strategy.

Keywords: Tourism; Culture; Local History, Mount Susuru

\section{PENDAHULUAN}

Pariwisata adalah salah satu aspek yang sangat penting untuk dikembangkan, karena dengan berkembangnya pariwisata akan mampu meningkatkan kesejahteraan masyarakat. Menurut UU No. 10 Tahun 2009, pariwisata berbagai macam kegiatan wisata dan 
Pengembangan Pariwisata Budaya Berbasis Situs Sejarah Lokal Gunung Susuru di Kabupaten Ciamis U. Runalan, Sri Pajriah, Aan Suryana

didukung berbagai fasilitas serta layanan yang disediakan oleh masyarakat, pengusaha, pemerintah, dan pemerintah daerah. Selain itu, pariwisata sebagai proses, kegiatan dan hasil yang didapat dari hubungan dan interaksi antara wisatawan, tourism-suppliers, pemerintah setempat, masyarakat setempat dan lingkungan sekitar yang dilibatkan ketertarikan dan tuan rumah dari pengunjung, "Tourism may be defined as processes, activities, and outcomes rising from the relationships and the interactions among tourist, tourism-suppliers, host governments, host communities, and surrounding enironments that are involved in the attracting and hosting of visitor" (Nafila, 2013).

Salah satu yang dapat dikembangkan dalam pariwisata adalah budaya. Pariwisata budaya adalah salah satu jenis pariwisata yang menjadikan budaya sebagai daya tarik utama. International Council on Monuments and Sites (ICOMOS) (2012) dalam Nafila (2013) menyatakan pariwisata budaya meliputi semua pengalaman yang didapat oleh pengunjung dari sebuah tempat yang berbeda dari lingkungan tempat tinggalnya. Selain itu, pariwisata budaya adalah jenis pariwisata dengan budaya berupa ide, kegiatan, dan artefak sebagai potensi daya tarik. Dimana tahun 2009, World Trade Organization menyatakan bahwa pariwisata budaya merupakan industri yang berkembang dengan pesat sejak tahun 90-an melebihi perkembangan industri pariwisata lainnya. Penyebabnya adalah adanya kerinduan terhadap nilai-nilai yang lebih dalam seperti agama, seni, dan sastra terutama oleh wisatawan mancanegara yang sibuk dengan hiruk-pikuk kehidupan modern (Larasati \& Rahmawati, 2017).

Dalam pariwisata budaya pengunjung diajak untuk mengenali budaya dan komunitas lokal, pemandangan, nilai dan gaya hidup lokal, museum dan tempat bersejarah, seni pertunjukan, tradisi dan kuliner dari populasi lokal atau komunitas asli. Kemudian Mappi (Asriady, 2016) dan (Prasodjo, 2017) lebih jelas mengemukakan bahwa beberapa aspek yang termasuk dalam objek pariwisata budaya diantaranya, adanya upacara kelahiran, taritarian tradisional, musik-musik tradisional, perkawinan, pakaian tradisional (pakaian adat), berbagai macam upacara (seperti turun ke sawah dan upacara panen), bangunan-bangunan bersejarah, cagar budaya, beberapa peninggalan tradisonal, kain tradisional (seperti kain tenun), pemeran festival budaya dan pertunjukan tradisional, hasil tekstil lokal, meseum sejarah dan budaya, serta adat-istiadat lokal lainnya. Daerah di Jawa Barat yang memiliki potensi pariwisata budaya yang banyak adalah Kabupaten Ciamis.

Kabupaten Ciamis merupakan sebuah daerah di Provinsi Jawa Barat yang memiliki pariwisata budaya yang cukup banyak dibandingkan daerah lainnya, salah satunya pariwisata budaya berbasis situs sejarah lokal. Berdasarkan catatan, situs sejarah di 
Kabupaten Ciamis berjumlah 133 situs. Namun, dalam kenyataannya hanya ada 36 situs sejarah lokal yang sudah digali dan dikembangkan (Tabel 1).

Tabel 1. Situs Budaya Sejarah Lokal di Kabupaten Ciamis

\begin{tabular}{cll}
\hline No. & $\begin{array}{c}\text { Data Cagar Budaya } \\
\text { Limpahan dari Dinas } \\
\text { Parawisata }\end{array}$ & \multicolumn{1}{c}{$\begin{array}{c}\text { Data Cagar Budaya Hasil Pendataan Dinas } \\
\text { Pendidian dan Kebudayaan Ciamis }\end{array}$} \\
\hline $1 \quad \begin{array}{l}\text { Astana Gede Kawali, } \\
\text { Karangkamulyan, Gunung } \\
\text { Padang, Batu Tulis Citapen, } \\
\text { Situ Lengkong, Bumi Alit, } \\
\text { Situs Garahan, Situs Batu } \\
\text { Tulis, Kampung Adat Kuta, } \\
\text { Gunung Susuru dan }\end{array}$ & $\begin{array}{l}\text { Kalap Kuning Lakbok, Kapunduhan Hutan Larangan } \\
\text { Panjalu, Makom Keramat Gunung Tilu Panumbangan, } \\
\text { Keramat Situ Gede. }\end{array}$ & $\begin{array}{l}\text { Situs Cagar Budaya Bojong Malang Cimaragas, } \\
\text { Keramat Seda Suci Cihaurbeuti, Umbu Leuit, Situs } \\
\text { Bojong Galuh, Situs Prabudimuntur Kertabumi, Situs }\end{array}$ \\
& $\begin{array}{l}\text { Samida, Kramat Situ Gede, Situs Pangrumasan, Makom } \\
\text { Pakuncen Ciamis, Situs Gunung Galuh Ciamis, Makom }\end{array}$ \\
& RAA Imbangara, Situs Jagabaya, Makom RAA \\
& Wiradikusuma, Makom Gandaria, Situs Paniisan, \\
& Kawasan Batu Tumpang, Curug Panganten Rancah, \\
& Asta Sanghyang Samida Rajadesa, Kadaleman \\
& Kawasen Banjarsari \\
\hline (Sumber: & https://www.harapanrakyat.com/2016/01/ini-36-situs-cagar-budaya-di-ciamis-yang- \\
sudah-dapat-legalitas/) &
\end{tabular}

Ada beberapa kasus yang terjadi dalam pengelolaan Situs Gunung Susuru. Sebelumnya kegiatan-kegiatan di situs sejarah ini dikelola oleh pihak keluarga, namun lama kelamaan ada kegiatan yang dikelola langsung oleh masyarakat dan pemerintahan setempat, seperti tradisi Merlawu yang dilaksanakan setiap tahun. Selain itu, situs sejarah ini juga pengelolaannya dibantu oleh kelompok Paguyuban Prabudimuntur dan Karangtaruna Ciptadimuntur. Namun, dalam prosesnya Kelompok Paguyuban Prabudimuntur mengalami permasalahan diantaranya keluarnya ketua kelompok paguyuban yang menyebabkan kegiatan paguyuban menjadi tidak berjalan sesuai rencana, sehingga saat ini ketua kelompok paguyuban dipegang oleh kepala desa sebelum ketua baru terpilih. Selain itu, pengelolaan di Situs Gunung Susuru juga dibantu oleh Kelompok Karangtaruna Ciptadimuntur, dimana kelompok ini bertugas untuk memperkenalkan situs sejarah ini ke luar daerah melalui kegiatan yang dilakukannya. Seperti yang diungkapkan Heryati (2019) bahwa Situs Gunung Susuru memiliki nilai sejarah yang tinggi dan harus dilestarikan oleh generasi selanjutnya. Namun, dalam kenyataannya masih banyak persoalan yang dihadapi dalam upaya mengembangkan pariwisata budaya Situs Gunung Susuru. Adapun beberapa permasalahan tersebut adalah kurangnya sumber daya manusia yang mampu mengelola situs sejarah, dimana pengelolaan Situs Gunung Susuru lebih banyak melibatkan kelaurga yang dianggap memiliki keturunan dengan kerajaan Galuh Kertabumi, sehingga menyebabkan belum adanya pengelola yang memiliki keilmuan 
khusus kesejarahan, serta kurangnya penguasaan bahasa asing yang dimiliki pengelola situs sejarah. Diakui Heryati bahwa pengelola situs sejarah hanya mendapatkan pelatihan melalui seminar ataupun kegiatan lainnya. Selain itu, kurangnya jumlah personil yang dilibatkan dalam pengelolaan situs sejarah ini menyebabkan beberapa titik tidak terurus. Persoalan lain yang dihadapi adalah kurangnya promosi daya tarik wisata yang dilakukan oleh pihak-pihak terkait dengan pengelolaan Situs Gunung Susuru. Seperti melalui penyebaran leaflet, pemasangan baliho, atau pun melalui tayangan iklan di TV, sehingga menyebabkan kunjungan masyarakat luar ke Situs Gunung Susuru masih rendah. Hal ini berdampak pada kurangnya keterlibatan masyarakat dalam pengelolaan situs sejarah ini, karena sebagaian masyarakat beranggapan yang harus mengelola tempat tersebut adalah orang-orang yang dianggap memiliki ikatan kekeluargaan. Adanya tanggapan masyarakat bahwa situs sejarah ini sering digunakan oleh orang-orang tertentu untuk melakukan kegiatan yang bertentangan dengan agama menyebabkan terjadinya konflik sosial diantara pengelola dengan masyarakat skitar. Sarana dan prasarana yang masih kurang menyebabkan pelayanan yang diberikan kurang optimal seperti masih kurangnya persediaan air bersih, sehingga pengunjung kesulitan untuk mendapatkannya, sehingga berdasarkan hal tersebut pengabdian ini penting untuk dilaksanakan supaya eksistensi situs Gunung Susuru tetap bertahan.

\section{BAHAN DAN METODE}

Kegiatan pengabdian ini menggunakan metode instruksional, dengan menggunakan pendekatan participatory planning, yaitu suatu pendekatan dimana seluruh unsur yang terlibat dalam perencanaan dan pengembangan kawasan wisata budaya diikutsertakan baik secara teoritis maupun praktis. Selanjutnya, menggunakan pendekatan potensi dan karakteristik ketersediaan produk budaya yang dapat mendukung keberlanjutan pengelolaan kawasan wisata budaya (Sastrayuda, 2010: 6).

\section{HASIL DAN PEMBAHASAN}

\section{A. Pelaksanaan Kegiatan Pengabdian}

Kegiatan pengabdian dilaksanakan di situs Gunung Susuru, Dusun Bunder, Desa Kertabumi, Kecamatan Cijeunjing, Kabupaten Ciamis. Jaraknya kira-kira 8 km sebelah timur kota Ciamis dan kota Banjar. Tinggalan arkeologis dari situs ini adalah berupa bangunan berundak, gua, dan sumur batu (https://dispar.ciamiskab.go.id/2017/04/12/situsgunung-susuru/). Situs ini pertama kali diketahui dari laporan Kantor Departemen 
Pendidikan Nasional Kabupaten Ciamis yang menginformasikan bahwa telah ditemukan tinggalan arkeologi di Dusun Bunder, Desa Kertabumi, Kecamatan Cijeungjing, Kabupaten Ciamis. Kawasan Kertabumi mencakup dua situs, yaitu situs Gunung Susuru dan Bojong Gandu. Di situs Gunung Susuru ada tiga batu datar yang terbuat dari batuan beku andesitik. Batu datar I berada di bagian timur laut Gunung Susuru, batu datar II berada di sebelah barat daya batu datar I berjarak sekitar $350 \mathrm{~m}$, sedangkan batu datar III berada di sebelah barat daya batu datar II berjarak sekitar $100 \mathrm{~m}$ (http://disparbud.jabarprov.go.id/wisata/dest-det.php?id=125\&lang=id).

Tahap awal pelaksanaan kegiatan pengabdian, yaitu persiapan dengan melakukan observasi tentang potensi pariwisata budaya yang ada di Desa Kertabumi, Kecamatan Cijeunjing, Kabupaten Ciamis. Berdasarkan hasil observasi menunjukan potensi pariwisata budaya yang bisa dikembangkan di Desa Kertabumi, Bojong, Kabupaten Ciamis adalah Situs Gunung Susuru yang merupakan peninggalan dari kerajaan Galuh Kertabumi. Di situs sejarah ini banyak peninggalan dari kerajaan Galuh, yaitu bangunan berundak, gua, dan sumur batu.

Selanjutnya, setelah tahap persiapan selesai, maka tim pengabdian langsung melaksanakan kegiatan pengabdian pada tanggal 28 Januari 2021 yang dilaksanakan secara virtual melalui aplikasi google meet dengan tema "Pengembangan Pariwisata Budaya Berbasis Situs Sejarah Lokal Gunung Susuru". Pada kegiatan tersebut dihadiri oleh perwakilan perangkat desa Kertabumi, perwakilan juru kunci situs Gunung Susuru, mahasiswa, serta tokoh masyarakat sebanyak 20 orang dari pukul 9.00-11.00. Pada pelaksanaan kegiatan pengabdian ini membahas tentang pengembangan pariwisata budaya berbasis sejarah lokal yang bisa dimanfaatkan untuk meningkatkan kesejahteraan ekonomi masyarakat sekitar mulai dari pengembangan produk wisata, analisis faktor internal dan eksternal Situs Gunung Susuru, strategi pengembangan pariwisata di situs Gunung Susuru, serta UU yang mengatur tentang pariwisata.

\section{B. Bentuk Produk Wisata Situs Gunung Susuru}

Situs Gunung Susuru yang berada di Desa Kertabumi, Kecamatan Cijeungjing, Kabupaten Ciamis merupakan situs peninggalan dari kerajaan Galuh Kertabumi. Dimana terdapat beberapa peninggalan bersejarah yang sampai sekarang masih dijaga dan dilestarikan oleh masyarakat sekitar. Keberadaan situs Gunung Susuru ini memberikan dampak bagi kehidupan masyarakat sekitar terutama dalam bidang ekonomi. Dalam hal ini, ada bentuk produk wisata yang dikembangkan di situs ini, yaitu baru hasil kerajinan 
Pengembangan Pariwisata Budaya Berbasis Situs Sejarah Lokal Gunung Susuru di Kabupaten Ciamis U. Runalan, Sri Pajriah, Aan Suryana

tangan masyarakat sekitar berupa caping (dudukuy) yang terbuat dari hatta. Sedangkan untuk produk lainnya masih belum dikembangkan. Hasil kerajinan tangan berupa dudukuy tersebut sudah terdaftar di Dinas Ekonomi Kreatif Kabupaten Ciamis, namun dalam pemasarannya masih belum optimal, karena terkendala oleh keadaan, terutama faktor SDM (Aditia, 2021).

Produk wisata bisa diidentifikasi dari beberapa jenis, yaitu:

1. Aspek Atraksi Alam/wisata alam seperti persawahan, perkebunan, hutan, sungai, dan air terjun. Pada aspek ini situs Gunung Susuru memiliki daya tarik wisata alam yang sangat indah, karena letak dari situs ini dikelilingi oleh dua sungai yaitu, Ci Leueur dan Ci Muntur.

2. Aspek atraksi budaya/wisata budaya seperti upacara, tradisi, seni pertunjukan yang khas/tarian sakral, bahasa, kerajinan tangan, makanan tradisional. (Situs Gunung Susuru). Pada aspek ini di situs Gunung Susuru terdapat tradisi yang diwariskan secara turun temurun yaitu Tradisi Merlawu.

3. Tradisi Merlawu merupakan rangkaian ritual yang dilakukan oleh masyarakat di Desa Kertabumi setiap tahun pada minggu terakhir bulan Rewah sebelum memasuki bulan suci Ramadhan. Tradisi Merlawu bukan acara ritual untuk memuja dan mengkultuskan, tetapi kegiatan rutin tahunan yang dilaksanakan oleh masyarakat Kertabumi untuk menghormati jasa leluhur yang telah "ngaheuyeuk nagri" (memerintah negara) Kertabumi yang menjadi cikal bakal Desa Kertabumi. Sejak dahulu masyarakat Kertabumi melaksanakan Tradisi Merlawu jauh dari ritual mistis. Tradisi Merlawu menjadi salah satu bentuk kearifan lokal yang masih terpelihara dengan baik di masyarakat Kertabumi. Merlawu berasal dari kata "mer" dan "lawuh". Kata "mer" dapat diartikan sebagai "bagi" seperti yang ada dalam kata "mertelu" yang berarti "dibagi tiga", sedangkan "lawuh" atau "lalawuh" diartikan sebagai "lauk pauk" atau menyuguhkan makanan dari hasil pertanian (Sofiani, 2020).

4. Aktifitas wisata seperti Trekking, aktifitas kesenian lainnya selain kesenian khas daerah tersebut, mempelajari makanan tradisional.

\section{Analisis faktor internal dan eksternal Pengembangan Pariwisata Budaya Berbasi Situs Sejarah Lokal Gunung Susuru}

Berdasarkan hasil wawancara pada kegiatan pengabdian diperoleh beberapa faktor internal dan eksternal. Pengaruh internal yaitu kekuatan dan kelemahan. Faktor eksternal 
yaitu peluang dan tantangan. Analisis faktor internal dan eksternal pengembangan pariwisata budaya berbasis situs sejarah lokal yang ada di Gunung Susuru meliputi:

1. Kekuatan: memiliki potensi untuk dikembangkan menjadi produk wisata berbasis budaya. Dalam hal ini situs Gunung Susuru memiliki potensi yang sangat luar biasa seperti potensi wisata alam berupa sungai dan keindahan alam, potensi wisata budaya berupa tradisi yang selalu dilakukan secara turun temurun, yaitu tradisi Merlawu.

2. Kelemahan: minimnya sumber daya manusia yang kompeten dan profesional di bidang pariwisata, tidak semua aktifitas budaya dapat dikomersialisasikan/dijual untuk kebutuhan pariwisata, keterbatasan dana untuk pengembangan fasilitas wisata dan pelatihan sumber daya manusia, belum memiliki kelompok sadar wisata, belum memiliki sistem pengelolaan pariwisata yang terencana dan sistematis, jumlah kunjungan wisatawan masih minim, dan belum ada paket wisata dari biro perjalanan/travel agent yang menawarkan aktifitas wisata.

3. Peluang: visi dan misi Dinas Pariwisata Kabupaten Ciamis mendukung perkembangan produk wisata berbasis budaya, pelestarian lingkungan fisik dan budaya sebagai dampak positif pengembangan pariwisata, peningkatan jumlah pendapatan dan ketersediaan lapangan pekerjaan, kemajuan teknologi informasi dan komunikasi

4. Ancaman: perubahan lingkungan fisik (pencemaran, limbah, sampah,dan polusi), bencana alam (gempa bumi, gunung meletus, banjir, tanah longsor), muncul destinasi (wisata) lain yang menawarkan produk serupa, terjadinya eksploitasi budaya secara berlebihan, sehingga tidak ada batasan antara aktifitas sakral dan seni pertunjukan, dan masyarakat dapat dengan mudah terpengaruh oleh budaya asing yang tidak sesuai dengan norma/adat setempat.

\section{Strategi pengembangan pariwisata di situs Gunung Susuru}

\section{Strategi Kekuatan-Peluang:}

a. Memanfaatkan Situs Gunung Susuru yang telah ditetapkan sebagai cagar budaya melalui manajemen pemasaran yang konsisten.

b. Memotivasi masyarakat setempat untuk mengelola sumber daya pariwisata yang dimiliki, melalui pelatihan (bahasa asing, keahlian pariwisata, pengetahuan tentang budaya) maupun pembinaan oleh Dinas Pariwisata, kalangan akademisi, dan swasta.

c. Memanfaatkan kemajuan teknologi untuk mendukung layanan kepariwisataan desa (dalam bentuk brosur, website khusus produk wisata, calendar of events, dan buku 
panduan wisata) sehingga dapat mendukung interpretasi wisatawan terhadap produk wisata berbasis budaya.

\section{Strategi Kekuatan-Ancaman:}

a. Memanfaatkan potensi wisata Situs Gunung Susuru untuk dikembangkan sebagai produk wisata berbasis budaya, dengan mengembangkan aktifitas wisata berbasis budaya yang nantinya wisatawan akan didampingi untuk mengelilingi situs dan lingkungan sekitarnya.

b. Memanfaatkan produk wisata budaya yang dimiliki untuk dijadikan daya tarik bagi wisatawan dengan membuat imitasi/duplikat dari kegiatan budaya setempat, hasil dari imitasi budaya tersebut dapat dirancang ke dalam time schedule yang bisa dipilih oleh wisatawan ataupun travel agent atau dapat juga melalui pemesanan (taylor made tour).

c. Memanfaatkan kearifan lokal masyarakat yang tertuang dalam awig-awig (aturan adat setempat) untuk meminimalisasi terjadinya eksploitasi sumber daya alam maupun budaya yang berlebihan akibat dari pariwisata, serta mengajak masyarakat untuk bersama-sama menjaga kebersihan dan mengurangi pencemaran lingkungan.

d. Memanfaatkan tokoh-tokoh masyarakat adat untuk dapat berperan aktif dalam pengembangan produk wisata berbasis budaya.

e. Memanfaatkan pihak dari luar desa untuk membantu pengembangan sumber daya pariwisata yang dimiliki, baik dari pemerintah kabupaten, pihak swasta seperti biro perjalanan wisata, praktisi ataupun akademisi.

\section{Kelemahan-Peluang}

a. Meningkatkan pengetahuan dan kompetensi masyarakat dalam bidang pariwisata, khususnya pelatihan/pembinaan kepada SDM tentang budaya pasar, karakteristik wisatawan, pemahaman terhadap budaya lokal, dan bahasa, dengan cara bekerja sama dengan pihak pemerintah kabupaten, pihak swasta, praktisi ataupun akademisi.

b. Meningkatkan kerja sama dengan pihak-pihak swasta khususnya dalam hal pengelolaan sampah, pembentukan standarisasi pembangunan dan pelayanan, serta perbaikan jaringan komunikasi.

c. Melakukan pemasaran yang konsisten dan bertanggung jawab dengan melibatkan semua pemangku kepentingan (pemerintah, swasta dan masyarakat lokal). 


\section{Strategi Kelemahan-Ancaman:}

a. Meningkatkan sistem pengelolaan pariwisata desa melalui pembentukan regulasi (desa adat dan dinas) yang jelas, sehingga eksploitasi budaya (komersialisasi/komodifikasi budaya dalam konteks pariwisata) yang berlebihan dapat dihindari. Pemerintah, pihak swasta, praktisi ataupun akademisi secara berkelanjutan memberikan pelatihan dan pembinaan kepada masyarakat setempat untuk dapat meningkatkan kompetensi keahlian masyarakat dalam mengelola sumber daya pariwisata yang dimiliki.

b. Menghidupkan kembali kelompok-kelompok seni yang dimiliki guna mendukung pengembangan produk wisata yang berbasis budaya.

\section{KESIMPULAN}

Berdasarkan hasil pengabdian yang telah dilaksanakan, maka dapat ditarik kesimpulan sebagai berikut:

1. Produk wisata yang dikembangakan di situs Gunung Susuru adalah berupa kerajinan tangan yaitu caping (dudukuy) yang terbuat dari hata. Namun, dalam pemasarannya belum berjalan secara optimal dikarenakan kurangnya faktor SDM.

2. Analisis faktor internal dan eksternal pengembangan pariwisata budaya berbasis situs sejarah lokal yang ada di Gunung Susuru meliputi kekuatan, kelemahan, peluang dan ancaman.

3. Strategi pengembangan pariwisata di situs Gunung Susuru meliputi strategi kekuatan peluang, strategi kekuatan ancaman, strategi kelemahan peluang, dan strategi kelemahan ancaman.

\section{DAFTAR PUSTAKA}

(https://dispar.ciamiskab.go.id/2017/04/12/situs-gunung-susuru/.

Aditia, Sandra (19 Tahun). Juru Pelihara Situs Gunung Susuru. Wawancara Tanggal 29 Maret 2021.

Heryati (45 Tahun). Juru Pelihara Situs Gunung Susuru. Wawancara Tanggal 6 September 2019.

http://disparbud.jabarprov.go.id/wisata/dest-det.php?id=125\&lang=id

https://www.harapanrakyat.com/2016/01/ini-36-situs-cagar-budaya-di-ciamis-yang-sudahdapat-legalitas/)

Larasati, N. K. R., \& Rahmawati, D. (2017). Strategi Pengembangan Pariwisata Budaya yang Berkelanjutan Pada Kampung Lawas Maspati, Surabaya. Jurnal Teknik ITS, 6(2), 529-533. https://doi.org/10.12962/j23373539.v6i2.25024 
Nafila, Oktaniza. 2013. Peran Komunitas Kreatif dalam Pengembangan Pariwisata Budaya di Situs Megalitikum Gunung Padang. Jurnal Perencanaan Wilayah dan Kota, 24(1): 65-80.

Prasodjo, Tunggul. 2017. Pengembangan Pariwisata Budaya dalam Perspektif Pelayanan Publik. Jurnal Office, 3(1): 7-12.

Sastrayuda, Gumelar S. 2010. Konsep Pengembangan Kawasan Wisata Budaya. Hand Out Mata Kuliah Concept Resort And Leisure, Strategi Pengembangan Dan Pengelolaan Resort And Leisure.

Sofiani, Y. (2020). NILAI-NILAI KARAKTER BERBASIS KEARIFAN LOKAL. Bihari: Pendidikan Sejarah dan Ilmu Sejarah, 3(2), 112-123.

UU No 10 Tahun 2009 Tentang Pariwisata. 